九州大学学術情報リポジトリ

Kyushu University Institutional Repository

\title{
Construction of rice chromosome specific DNA Libraries using chromosome microdissection technique and its application for mapping
}

Ikeda, Kosuke

Plant Breeding Laboratory, Division of Genetics and Plant Breeding, Department of Applied Genetics and Pest Management, Faculty of Agriculture, Graduate School, Kyushu University

Naka, S

Plant Breeding Laboratory, Division of Genetics and Plant Breeding, Department of Applied Genetics and Pest Management, Faculty of Agriculture, Graduate School, Kyushu University

Egashira, M

Department of Human Genetics, Nagasaki University School of Medicine

Matsumoto, M

Department of Human Genetics, Nagasaki University School of Medicine

他

https://doi.org/10.5109/24359

出版情報：九州大学大学院農学研究院紀要. 45 (1)，pp.73-82，2000-11. Kyushu University バージョン：

権利関係 : 


\title{
Construction of rice chromosome specific DNA libraries using chromosome microdissection technique and its application for mapping
}

\author{
Ikeda, K., S. Naka, M. Egashira*, M. Matsumoto*, N. Niikawa*, \\ N. Iwata and A. Yoshimura \\ Plant Breeding Laboratory, Division of Genetics and Plant Breeding, Department of \\ Applied Genetics and Pest Management, Faculty of Agriculture, Graduate School, \\ Kyushu University, Fukuoka 812-8581, Japan \\ (Received July 31, 2000 and accepted August 18, 2000)
}

\begin{abstract}
The DNA libraries derived from the entire chromosomes 1, 4, 7 and 9 , and the extra chromosomes of acrotrisomics (Acro5a) were constructed using the chromosome microdissection technique. Fluorescence in situ hybridization (FISH) was used to identify the origins of the constructed DNA libraries. DNA libraries from the entire chromosomes 1, 4 and 9 would be available for the identification of chromosome on FISH. In addition, the origin of DNA libraries from the entire chromosome 7 and the extra chromosomes of Acro5a were identified by dot blot hybridization. One hundred sixty and 587 clones were obtained from DNA libraries of the entire chromosomes 1 and 4, respectively. Sixty-three of these clones were surveyed for polymorphism among six varieties. Forty-three unique clones, 35 clones for polymorphism and 20 multicopy clones were obtained. Two of 160 clones and three of 587 clones were mapped on RFLP linkage map using recombinant inbred lines.
\end{abstract}

\section{INTRODUCTION}

Chromosome microdissection technique has been developed for genome DNA analysis of specific chromosome regions. This technique is used for construction of DNA libraries derived from target regions on chromosome preparation. The first chromosome microdissection technique was used in Drosophila (Scalenghe et al., 1981), then mouse (Röhme et al., 1984) and human (Lüdecke et al., 1989; Lüdecke et al., 1990; Kao and Yu, 1991; Hadano et al., 1991; Hirota et al., 1992). DNA libraries obtained using this technique can be utilized as probes for chromosome painting in fluorescence in situ hybridization (FISH) (Ohta et al., 1993).

In comparison to genomic DNA analysis, chromosome microdissection technique is better because it is possible to obtain DNA from special regions on chromosome preparation. Since a number of clones could be derived from special chromosome regions, DNA relative to target genes is selected in high frequency. DNA fragments could be obtained from the centromere, telomere, interchanged point and breakpoints directly, hence, utilizing their DNA fragments will lead to contribute analysis of mechanism and construction for centromere, telomere and chromosome aberration.

Fukui et al. (1992) reported that chromosome microdissection technique might be used in rice and barley. Construction of chromosome region specific DNA libraries was

\footnotetext{
* Department of Human Genetics, Nagasaki University School of Medicine, Nagasaki 852-8523, Japan
} 
made in rice (Nonomura et al., 1994), wheat (Vega et al., 1994) and barley (Busch et al., 1995, 1996).

Here, we constructed chromosome regions specific DNA libraries from the entire chromosomes and an acrocentric chromosome using microdissection technique to locate their DNA clones on RFLP linkage maps.

\section{MATERIALS AND METHODS}

\section{Chromosome preparation for microdissection}

Seeds of Japonica variety "Nipponbare" and acrotrisomics (Acro5a; Ikeda et al., 1999) having an extra acrocentric chromosome for chromosome 5 were used for chromosome preparation. The acrocentric chromosomes for chromosome 5 in addition to the entire chromosomes 1, 4, 7 and 9 were targeted for microdissection. Excised roots from germinating seeds at $30^{\circ} \mathrm{C}$ were pre-treated with $1.5 \mathrm{mM}$ 8-oxyquinoline for $1.5-2 \mathrm{~h}$ at $20^{\circ} \mathrm{C}$, and were fixed with a fixative ( 3 methanol : 1 acetic acid) for $2 \mathrm{~h}$ at room temperature. Their roots were stocked in $70 \%$ ethanol at $4{ }^{\circ} \mathrm{C}$. Chromosome preparation was based on the modified method of Kurata and Omura (1978). Stocked roots were immersed in distilled water for 30-60 min at room temperature. Root tips were treated with the enzyme solution which contained $3 \%$ cellulase (Onozuka RS), 1.5\% pectolyase $\mathrm{Y} 23,7.5 \mathrm{mM} \mathrm{KCl}$ and $7.5 \mathrm{mM}$ EDTA adjusted to $\mathrm{pH} 4.0$ for $31-33 \mathrm{~min}$ at $37^{\circ} \mathrm{C}$. Treated root tips were immersed in distilled water for $30-60 \mathrm{~min}$. Prometaphase chromosomes were air dried then fixed in 9 methanol : 1 acetic acid and steamed using water bath at $65^{\circ} \mathrm{C}$ for $20-30$ seconds. Well spread chromosomes were washed using $100 \%$ methanol and stained with $10 \%$ Giemsa solution for $2 \mathrm{~h}$.

\section{Microdissection and PCR amplification of chromosome DNA}

Procedures followed those described previously in human (Hirota et al., 1992; Ohta et al., 1993). A fragment of chromosome was microdissected under an inverted microscope with the use of a fine glass needle, guided by micromanipulator. Collected chromosome pieces were treated with $2-3 \mathrm{nl}$ of proteinase $\mathrm{K}$ solution $(0.5 \mathrm{mg} / \mathrm{ml}$ proteinase $\mathrm{K}, 0.1 \% \mathrm{SDS}$, $10 \mathrm{mM}$ Tris-HCl $(\mathrm{pH} 7.5), 10 \mathrm{mM} \mathrm{NaCl})$ at $37^{\circ} \mathrm{C}$ for $3 \mathrm{~h}$. The extracted DNA was digested with Sau 3AI solution (50 U/ml Sau 3AI, $100 \mathrm{mM} \mathrm{NaCl}, 10 \mathrm{mM}$ Tris $-\mathrm{HCl}(\mathrm{pH} 7.5), 7 \mathrm{mM}$ $\mathrm{MgCl}_{2}$ ) at $37^{\circ} \mathrm{C}$ for $4 \mathrm{~h}$. The DNA fragments were amplified with the primer-linker PCR method. Ligation reaction was performed using ligation mixture (a 10 mer linker [MboL1; 5'-GATCCATGTC-3'], a 24 mer primer [NlaM1; 5'-CGGGAATTCTGGCTCTGCGACATG-3'], $350 \mathrm{U} / \mathrm{ml}$ T4 DNA ligase in ligation buffer) at $15^{\circ} \mathrm{C}$ for $1 \mathrm{~h}$. PCR was performed as follows: The first cycle, $73^{\circ} \mathrm{C}(2 \mathrm{~min}), 94^{\circ} \mathrm{C}(3 \mathrm{~min}), 62^{\circ} \mathrm{C}(2 \mathrm{~min}), 72^{\circ} \mathrm{C}(2 \mathrm{~min})$. Followed by 30 cycles, $94^{\circ} \mathrm{C}(2 \mathrm{~min}), 62^{\circ} \mathrm{C}(2 \mathrm{~min}), 72^{\circ} \mathrm{C}(2 \mathrm{~min})$. Lastly at $72^{\circ} \mathrm{C}(5 \mathrm{~min})$.

\section{Fluorescence in situ hybridization (FISH)}

Procedures for FISH involved a modification of the method described previously (Ohta et al., 1993). The second PCR products were used for probes in FISH, a small volume $(5 \mathrm{ml})$ of the first PCR products was amplified by 12 cycles, $94^{\circ} \mathrm{C}(2 \mathrm{~min}), 62^{\circ} \mathrm{C}$ $(2 \mathrm{~min}), 72^{\circ} \mathrm{C}(2 \mathrm{~min})$, in a reaction mixture containing $100 \mathrm{mM}$ biotin-16-dUTP and $100 \mathrm{mM}$ dTTP. The second PCR products with $10 \mathrm{mg}$ sonicated salmon DNA and $0-8 \mathrm{mg}$ 
sonicated DNA of rice cultivar "IR24" were used for hybridization. The DNA mixture was ethanol-precipitated, resuspended in $10 \mathrm{ml}$ formamide, denatured at $80^{\circ} \mathrm{C}$ for $10 \mathrm{~min}$, and mixed with a hybridization solution consisting of $40 \mathrm{mg}$ bovine serum albumin (BSA), $4 \times$ SSC and $20 \%$ dextran sulfate. The hybridization was performed at $37^{\circ} \mathrm{C}$ for $12-18 \mathrm{~h}$. The slides were washed in $50 \%$ formamide and $2 \times \mathrm{SSC}(15 \mathrm{~min})$, then $2 \times \mathrm{SSC}(10 \mathrm{~min}), 1 \times$ $\mathrm{SSC}(5 \mathrm{~min})$ and $4 \times \mathrm{SSC}(5 \mathrm{~min})$ each at $37^{\circ} \mathrm{C}$; incubated with $0.5 \mathrm{mg}$ fluorescence isothiocyanate (FITC)-conjugated avidin with $4 \times$ SSC and $1 \%$ BSA at $37^{\circ} \mathrm{C}$ for $45-60 \mathrm{~min}$; rinsed in $4 \times \mathrm{SSC}$ with shaking ( $5 \mathrm{~min}$ ), $4 \times \mathrm{SSC}$ containing $0.02 \%$ Tween 20 with shaking ( $7 \mathrm{~min}), 4 \times \mathrm{SSC}$ with shaking $(3 \mathrm{~min})$ and $2 \times \mathrm{SSC}(30-60 \mathrm{sec})$ each at room temperature in the dark. The chromosomes were stained with $0.1-0.2 \mathrm{mg} / \mathrm{ml}$ propidium iodide (PI), and then were observed under fluorescence microscope.

\section{Dot blot hybridization}

PCR products derived from target chromosomes and genomic DNA of "Nipponbare" as control were used for dot blotting on nylon membranes. The RFLP markers labeled with $\left(\alpha-{ }^{32} \mathrm{P}\right)$ dCTP were utilized for Southern hybridization (Table 1$)$. Dot signals were detected when a part of PCR products is homologous with the RFLP marker.

Table 1. RFLP clones used for identification of PCR products by Southern analysis

\begin{tabular}{cllllll}
\hline Chromosome & \multicolumn{7}{c}{ RFLP clones } \\
\hline 1 & Npb302 & Npb346 & Npb359 & & & \\
2 & Npb42 & & & & & \\
3 & Npb48 & & & & & \\
4 & Npb49 & Npb177 & Npb237 & Npb247 & Npb311 & R288 \\
5 & Npb25 & Npb105 & Npb208 & Npb292 & Npb297 & R2232 \\
6 & Npb172 & Npb342 & & & & \\
7 & Npb106 & Npb117 & Npb338 & Npb379 & R1440 & \\
8 & Npb278 & & & & & \\
9 & Npb13 & Npb103 & Npb293 & & & \\
10 & Npb37 & & & & & \\
11 & Npb52 & Npb181 & Npb257 & & & \\
\hline
\end{tabular}

The Npb clones were from Saito et al. (1991) and the others were from Kurata et al. (1994)

\section{Characterization and polymorphism of clones}

Procedures for cloning followed that described previously in human (Hirota et al. 1992). PCR products were digested with Eco RI at $37^{\circ} \mathrm{C}$ for $4 \mathrm{~h}$. DNA fragments were ligated to dephosphorylated Eco RI-cut pUC19 in reaction mixture at $15^{\circ} \mathrm{C}$ for $8 \mathrm{~h}$, and used for transformation. Recombinant plasmids were picked out and stocked at $-80^{\circ} \mathrm{C}$. DNA clones were used for characterization and polymorphism using four Japonica varieties; "Nipponbare", "Taichung 65", "Asominori" and "Kinmaze", and two Indica varieties; "IR24" and "DV85". The genomic DNA of six varieties extracted by CTAB method (Rogers and Bendich 1988) were digested with six enzymes (Bam HI, Bgl II, Dra I, Eco RI, Eco RV, Hin dIII). The digested DNA was transferred to a nylon membrane 
after electrophoresis. DNA clones labeled with $\left(\alpha{ }^{32} \mathrm{P}\right) \mathrm{dCTP}$ were utilized for probes in Southern hybridization, as described by McCouch et al. (1988).

\section{Mapping of clones}

Five DNA clones detected as polymorphism between Asominori and IR24 were utilized for mapping using 71 recombinant inbred lines (RILs) derived from their crosses. Five clones, 1W26 and 1W49 from the entire chromosome 1, 4W203, 4W206 and 4W221 from the entire chromosome 4 were mapped based on RFLP linkage map established by Tsunematsu et al. (1996) using RILs. Linkage analysis was performed using MAPMAKER (Lander et al. 1987) and Map Manager (Manly 1993) as described by Tsunematsu et al. (1996).

\section{RESULTS AND DISCUSSION}

\section{PCR products and FISH}

The results showed that chromosome region specific DNA libraries could be constructed within the 200 to $500 \mathrm{bp}$ DNA fragments (Fig. 1). Using FISH with suppression to non-specific regions, chromosomes 1, 4 and 9 are shown (Fig. 2b-d). Chromosome 1 is the longest chromosome, chromosome 4 is a subtelocentric chromosome and chromosome 9 is a nucleolar chromosome. Using FISH with non-suppression, specific chromosome regions plus other chromosome regions were painted. These results suggest that non-specific DNA regions share to each chromosome in rice. Non-specific DNA regions were believed to exist in heterochromatin regions because the painted

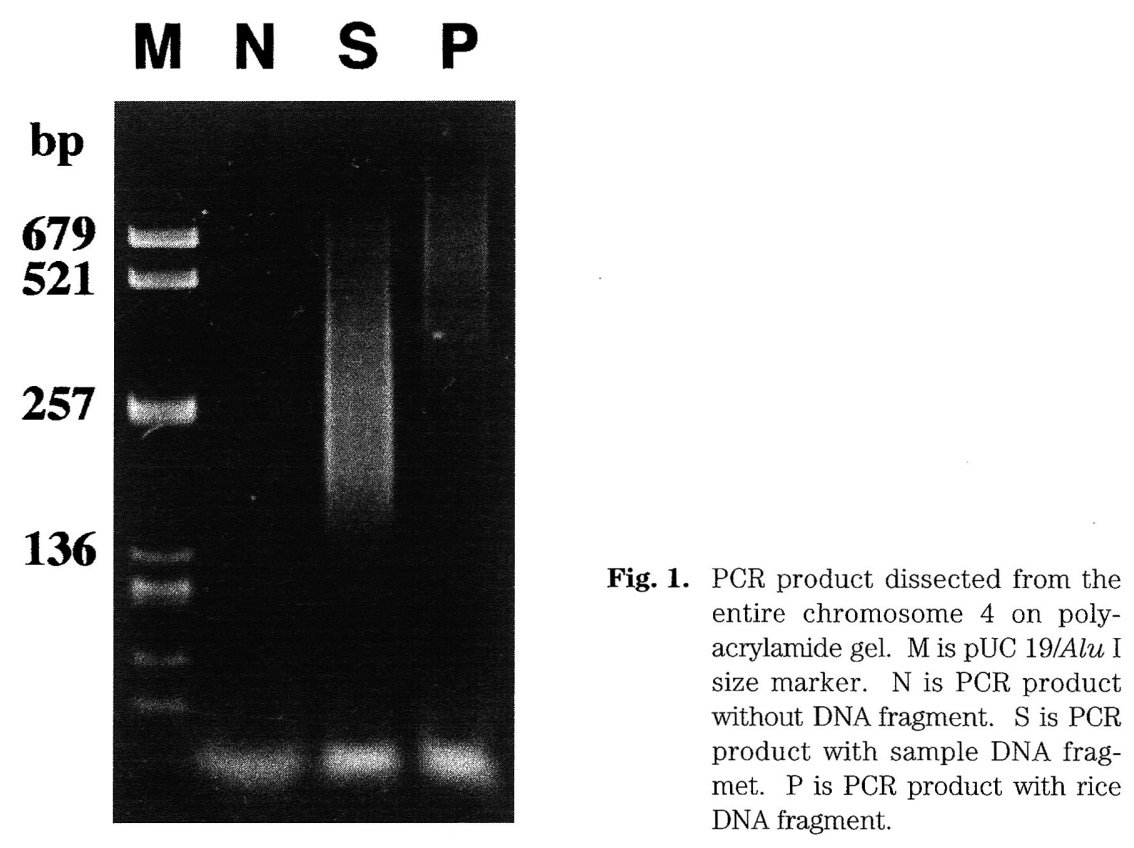




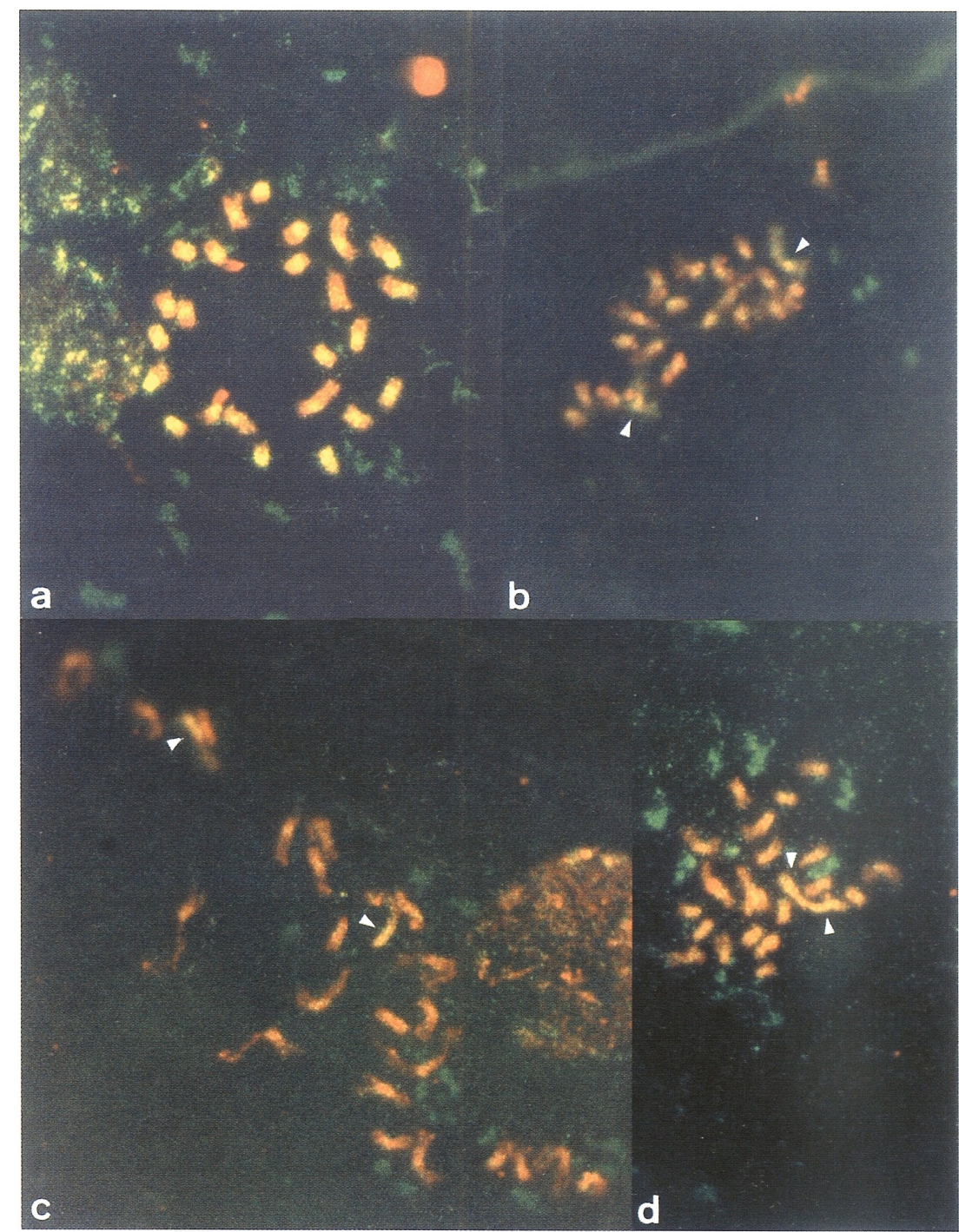

Fig. 2. a-d. Fluorescence in situ hybridization (FISH) analysis using DNA fragment dissected from the entire chromosome 1 (b), 4 (a and c) and 9 (d). (a): FISH without suppression. (b, $c$ and d): FISH with sonicated rice total DNA as competitor. Arrowheads represent chromosome specific signals.

regions correspond to heterochromatin region stained by Giemsa. In human, it has been reported that suppression to non-specific DNA regions is indispensable for painting specific regions (Lengauer et al. 1990). Suppression to non-specific DNA regions is also indispensable for painting specific regions in rice. However, painting for specific regions was not detected on the entire chromosome 7 and the acrocentric chromosome for 
chromosome 5 using FISH. This may be attributed to the amplified DNA fragments which were almost non-specific DNA consisting of heterochromatin.

\section{Dot blot hybridization}

The construction of chromosome region specific DNA libraries was confirmed using dot blot hybridization (Fig. 3). Signals were detected on XNpb 302 but not on $X N p b 346$ and 359, when RFLP markers XNpb 302, 346 and 359 located on chromosome 1 were used for dot blot hybridization. For entire chromosomes 4 and 9 , signals were detected at $X N p b 49,177$ and 247 and at $X N p b 13,103$ and 293, respectively. For entire chromosome 7, signals were detected on $X N p b 117$ but not on $X N p b 106$ and 379 . For the extra chromosome of Acro5a, signals were detected on XNpb 208, 292 and R2232 but not on $X N p b 25$ and 297. These results agreed with our previous observations (Ikeda $e t$ al., 1999). Therefore, FISH as well as dot blot hybridization may be utilized for identification of DNA libraries. The results suggested that the chromosome region specific DNA libraries for the acrocentric chromosome could be constructed.

Using RFLP markers not located on target chromosomes, signals were detected on several loci. This suggests that the homology was high between DNA fragments and RFLP markers located on chromosomes except the target chromosome.

\section{Characterization and polymorphism of clones}

One hundred sixty and 587 DNA clones from entire chromosomes 1 and 4 were obtained, respectively. Twenty-eight DNA clones in 160 clones and 35 clones in 587 clones

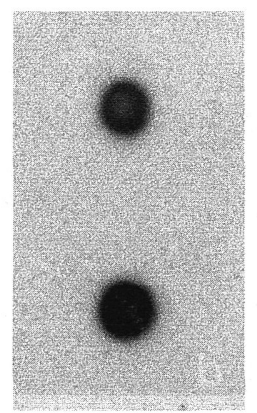

Control
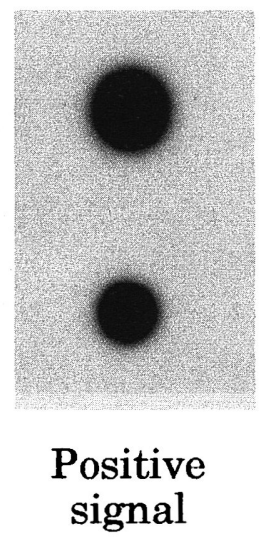
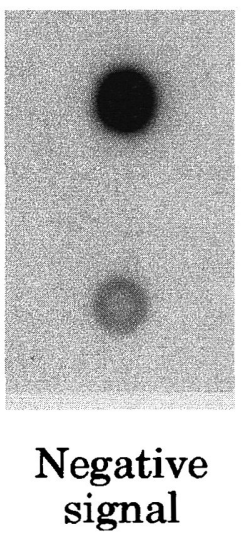

Fig. 3. Southern analysis of rice RFLP clones to PCR products obtained by microdissection. In each autoradiogram, and the upper dot is total Nipponbare DNA as a control, and the lower is PCR products of chromosome 7. Positive signal is shown on the left as a control, positive signal using Npb379 on chromosome 7 on the center, negative signal using Npb342 on chromosome 6 on the right. 
were characterized (Fig. 4). Twenty-eight clones from entire chromosome 1 have single and multi-copy sequence, respectively (Table 2). Nineteen out of 20 clones showed polymorphism among six varieties. In chromosome 4, 23 clones were single-copy, 16 of these clones showed polymorphism among six varieties (Table 2). Twelve clones were multi-copy sequence. In total, 43 clones (68.3\%) were single-copy sequence and 20 clones $(31.7 \%)$ were multi-copy sequence. Thirty-five clones $(55.6 \%)$ showed polymorphism among six varieties mainly between Japonica and Indica.

In Japonica variety "Nipponbare", 37.9\% of 974 DNA clones indicate multi-copy sequence, $28.8 \%$ of 974 clones show polymorphism between Indica Kasalath and Japonica

\section{$\begin{array}{lllllllllllllllllll}1 & 2 & 3 & 4 & 5 & 6 & 1 & 2 & 3 & 4 & 5 & 6 & 1 & 2 & 3 & 4 & 5 & 6\end{array}$}



Fig. 4. a-c. Autoradiograms showing characterization of microclones obtained using microdissection in Japonica rice and Indica rice. (a): RFLP (single-copy) using 4W225. DNA was digested with Bgl II. Lane 1: Japonica "Nipponbare", lane 2: Japonica "Taichung 65", lane 3: Japonica "Asominori", lane 4: Indica "IR24", lane 5: Japonica "Kinmaze", lane 6: Indica "DV85".

Table 2. Characterization of microclones by Southern analysis

\begin{tabular}{|c|c|c|c|c|}
\hline \multirow{2}{*}{$\begin{array}{l}\text { Hybridization } \\
\text { signal }\end{array}$} & \multicolumn{4}{|c|}{$\begin{array}{l}\text { Microclones obtained from chromosome } \\
\text { specific library of the entire chromosomes }\end{array}$} \\
\hline & \multicolumn{2}{|c|}{ Chromosome 1} & \multicolumn{2}{|c|}{ Chromosome 4} \\
\hline Single-copy & 20 & (71) & 23 & (66) \\
\hline RFLP & \multicolumn{2}{|c|}{19} & \multicolumn{2}{|c|}{16} \\
\hline No RFLP & \multicolumn{2}{|c|}{1} & \multicolumn{2}{|c|}{7} \\
\hline Multi-copy & 8 & (29) & 12 & (34) \\
\hline Total & 28 & $(100)$ & 35 & $(100)$ \\
\hline
\end{tabular}

( ): Percentages relative to total. 
Fl 134 (Saito et al. 1991). In Indica variety "IR36", 58\% and $42 \%$ of 210 clones indicate single-copy and multi-copy sequence, respectively (McCouch et al. 1988). The frequency for multi-copy in this study is comparable to the result obtained by Saito et al. (1991) although the frequency of polymorphism we obtained (55.6\%) was higher than theirs. Such differences could be attributed to the type of varieties used in polymorphism survey.

\section{Chromosome 1}

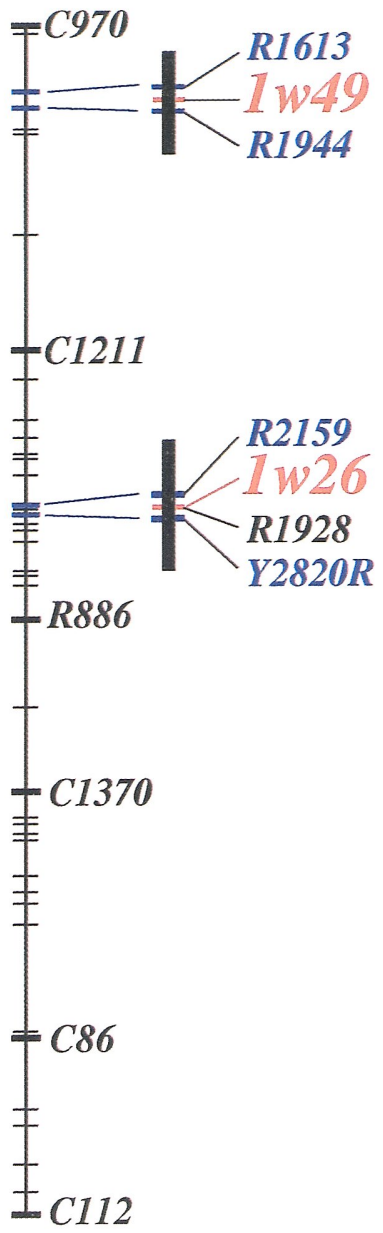

\section{Chromosome 4}



$=1 \mathrm{cM}$

Fig. 5. Location of microclones to RFLP linkage maps (Tsunematsu et al. 1996) on chromosomes 1 and 4. Microclones indicated by red numbers were mapped using recombinant inbred lines. 


\section{Mapping of clones}

On chromosome 1, 1W26 and 1W49 were mapped at the distance of $0 \mathrm{cM}$ from $R 1928$ and at the distance of $0.8 \mathrm{cM}$ from both $R 1944$ and $R 1613$, respectively (Fig. 5). Our results suggest that $1 \mathrm{~W} 26$ was located at the region near centromere of the long arm of chromosome 1 whereas $1 \mathrm{~W} 49$ was located at the short arm of chromosome 1 . This supported the previous observations made by Harushima et al. (1998).

On chromosome 4, 4W203 was mapped at the distance of $0.8 \mathrm{cM}$ from $X N p b 335-2$ and $2.4 \mathrm{cM}$ from $K y 5$. The $4 \mathrm{~W} 206$ locus was mapped at the distance $0 \mathrm{cM}$ from $R 288$, whereas $4 \mathrm{~W} 221$ was mapped at the distance of $0.8 \mathrm{cM}$ from $R 2737$. The $4 \mathrm{~W} 206$ locus was located at the region of centromere; 4W203 and 4W221 were both located at the light stained region on the long arm of chromosome 4 (Ikeda et al. 1999).

\section{REFERENCES}

Busch, W., R. G. Herrmann and U. Hohmann (1996) Repeated DNA sequences isolated by microdissection. II. Comparative analysis in Hordeum vulgare and Triticum aestivum. Theor. Appl. Genet. 93: 164-171.

Busch, W., R. Martin, R. G. Herrmann and U. Hohmann (1995) Repeated DNA sequences isolated by microdissection. I. Karyotyping of barley (Hordeum vulgare L.). Genome 38: 1082-1090.

Fukui, K., M. Minezawa, Y. Kamisugi, M. Ishikawa, N. Ohmido, T. Yanagisawa, M. Fujishita and F. Sakai (1992). Microdissection of plant chromosomes by argon-ion laser beam. Theor. Appl. Genet. 84: $787-791$.

Hadano, S., M. Watanabe, H. Yokoi, M. Kogi, I. Kondo, H. Tsuchiya, I. Kanazawa, K. Wakasa and J. E. Ikeda (1991) Laser microdissection and single unique primer PCR allow generation of regional chromosome DNA clones from a single human chromosome. Genomics 11: 364-373.

Harushima, Y., M. Yano, A. Shomura, M. Sato, T. Shimano, Y. Kuboki, T. Yamamoto, S. Y. Lin, B. A. Antonio, A. Parco, H. Kajiya, N. Huang, K. Yamamoto, Y. Nagamura, N. Kurata, G. S. Khush and T. Sasaki (1998) A high-density rice genetic linkage map with 2275 markers using a single $F_{2}$ population. Genetics 148: 479 - 494 .

Hirota, T., K. Tsukamoto, H. X. Deng, K. I. Yoshiura, T. Ohta, T. Tohma, T. Kibe, N. Harada, Y. Jinno and N. Niikawa. (1992) Microdissection of human chromosomal regions 8q23.3-q24.11 and 2q33-qter: Construction of DNA libraries and isolation of their clones. Genomics 13: $349-354$.

Ikeda, K., H. Yasui, A. Yoshimura and N. Iwata (1999) Identification of acrotrisomics and secondary trisomics of rice. Bull. Fac. Agr. Kyushu Univ. 53(1-4):1-12.(Japanese with English summary)

Kao, F. T. and J. W. Yu (1991). Chromosome microdissection and cloning in human genome and genetic disease analysis. Proc. Natl. Acad. Sci. 88: 1844-1848.

Kurata, N., Y. Nagamura, K. Yamamoto, Y. Harushima, N. Sue, J. Wu, B. A. Antonio, A. Shomura, T. Shimizu, S-Y. Lin, T. Inoue, A. Fukuda, T. Shimano, Y. Kuboki, T. Toyama, Y. Miyamoto, T. Kirihara, K. Hayasaka, A. Miyao, L. Monna, H. S. Zhong, Y. Tamura, Z-X. Wang, T. Momma, Y. Umehara, M. Yano, T. Sasaki and Y. Minobe (1994) A 300 kilobase interval genetic map of rice including 883 expressed sequences. Nature Genetics 8: 365-372.

Kurata, N. and T. Omura (1978) Karyotype analysis in rice. I. A new method for identifying all chromosome pairs. Jpr. J. Genet. 53: 251-255.

Lander, E. C., P. Green, J. Abrahamson, A. Barlow, M. J. Daly, S. E. Lincoln and L. Newburg (1987) MAPMAKER: An interactive computer package for constructing primary genetic linkage maps of experimental and natural populations. Genomics 1: 174-181.

Lengauer, C., H. Riethman and T. Cremer (1990) Painting of human chromosomes with probes generated from hybrid cell lines by PCR with Alu and L1 primers. Hum. Genet. 86: 1-6.

Lüdecke, H. J., G. Senger, U. Claussen and B. Horsthemke (1989) Cloning defined regions of the human genome by microdissection of banded chromosomes and enzymatic amplification. Nature $\mathbf{3 3 8}$ : $348-350$.

Lüdecke, H. J., G. Senger, U. Claussen and B. Horsthemke (1990) Construction and characterization of band-specific DNA libraries. Hum. Genet. 84: 512-516. 
Manly, K. F. (1993) A Macintosh program for storage and analysis of experimental genetic mapping data. Mammalian Genome 4: 303-313.

McCouch, S. R., G. Kochert, Z. H. Yu, Z. Y. Wang, G. S. Khush, W. R. Coffman and S. D. Tanksley Molecular mapping of rice chromosomes. Theor. Appl. Genet. 76: 815-829.

Nonomura, K. I., N. Matsumoto, A. Yoshimura, N. Niikawa and N. Iwata (1994) Chromosome 4 specific DNA library of rice by microdissection technique. Rice Genet. Newsl. 11: 180-182.

Ohta, T., T. Tohma, H. Soejima, Y. Fukushima, T. Nagai, K. Yoshiura, Y. Jinno and N. Nikawa (1993) The origin of cytologically unidentifiable chromosome abnormalities: six cases ascertained by targeted chromosome-band painting. Hum. Genet. 92: 1-5.

Rogers, S. O. and A. J. Bendich (1988) Extraction of DNA from plant tissues. Plant Molecular Biology Manual A6: $1-10$.

Röhme, D., H. Fox, B. Herrmann, A. M. Frischauf, J. E. Edstr_m, P. Mains, L. M. Silver and H. Lehrach (1984) Molecular clones of the mouse $t$ complex derived from microdissected metaphase chromosomes. Cell 36: 783-788.

Saito, A., M. Yano, N. Kishimoto, M. Nakagahra, A. Yoshimura, K. Saito, S. Kuhara, Y. Ukai, M. Kawase, T. Nagamine, S. Yoshimura, O. Ideta, R. Onsawa, Y. Hayano, N. Iwata and M. Sugiura (1991) Linkage map of restriction fragment length polymorphism loci in rice. Japan. J. Breed. 41: 665-670.

Scalenghe, F., E. Turco, J. E. Edström, V. Pirrotta and M. Melli (1981) Microdissection and cloning of DNA from a specific region of Drosophila melanogaster polytene chromosomes. Chromosoma (Beri.) 82: 205-216.

Tsunematsu, H., A. Yoshimura, Y. Harushima, Y. Nagamura, N. Kurata, M. Yano, T. Sasaki and N. Iwata (1996) RFLP framework map using recombinant inbred lines in rice. Breed. Sci 46: 279-284.

Vega, J. M., S. Abbo, M. Feldman and A. A. Levy (1994) Chromosome painting in plants: In situ hybridization with a DNA probe from a specific microdissected chromosome arm of common wheat. Proc. Natl. Acad. Sci. 91: 12041-12045. 